\title{
Przewlekłe zapalenie drobnych gruczołów ślinowych u pacjentki z liszajem twardzinowym — opis przypadku
}

\author{
Chronic inflammation of small salivary glands in the course \\ of lichen sclerosus - a case report \\ Zakład Chorób Błony Śluzowej Jamy Ustnej i Przyzębia, Uniwersytet Medyczny w Łodzi \\ DOI: http://dx.doi.org/10.20883/df.2018.36
}

\section{STRESZCZENIE}

Zapalenie ślinianek obejmuje szereg jednostek chorobowych gruczołów ślinowych o zróżnicowanej etiologii. Procesem zapalnym mogą zostać objęte duże gruczoły odpowiedzialne za wytwarzanie śliny, takie jak ślinianki przyuszne, podżuchwowe i podjęzykowe oraz drobne gruczoły ślinowe, znajdujące się na wargach, podniebieniu, języku i policzkach. Czynnikami wywołującymi dane schorzenia mogą być infekcje wirusowe, zakażenia bakteryjne oraz czynniki autoimmunologiczne, a proces zapalny przebiega w sposób ostry, przewlekły lub przewlekle zaostrzony. Zmiany o typie liszaja twardzinowego rzadko występują w jamie ustnej. Najczęściej dotyczą okolic narządów płciowych, ale również mogą pojawiać się na skórze całego ciała. W pracy przedstawiono opis przypadku wystąpienia przewlekłego zaostrzonego zapalenia drobnych gruczołów ślinowych u 64-letniej pacjentki z liszajem twardzinowym.

Słowa kluczowe: przewlekłe zapalenie ślinianek, liszaj twardzinowy.

\section{ABSTRACT}

Sialadenitis includes a number of infections of the salivary glands with different etiology. Both large salivary glands responsible for production of saliva like parotid, submandibular, sublingual as well as small salivary glands, which are located on the lips, palate, tongue and cheeks, can be affected by inflammatory conditions. Virus and bacterial infections and autoimmunological disorders can be the causative factors, and the presentation may be acute, chronic or chronic exacerbated. Lichen sclerosus (LS) occurs very rarely at the oral mucosal sites. LS is the most commonly affects the anogenital region, but it can also involve any area of the skin. Here, we present the case of a 64-year-old patient with chronic exacerbated inflammation of small salivary glands in the course of lichen sclerosus.

Keywords: chronic sialadenitis, lichen sclerosus.

\section{Wstęp}

Zapalenie gruczołów ślinowych jest najczęściej spotykanym rodzajem zmian tych narządów. Pacjenci zgłaszają obrzęki w okolicy występowania ślinianek, dolegliwości bólowe, nieprzyjemny posmak w ustach czy uczucie suchości [1]. Objawy mogą być wywołane ostrą lub przewlekłą infekcją wirusową i bakteryjną, chorobami IgG4-zależnymi (lgG4-RS), powstawaniem kamieni w gruczołach oraz przewodach wyprowadzających, ziarniniakowym i limfocyto-nabłonkowym zapaleniem ślinianek lub jako powikłanie po przeprowadzonym leczeniu [2-7]. Najczęściej zmiany chorobowe obejmują duże gruczoły ślinowe, chociaż proces zapalny może również dotyczyć tych mniejszych ślinia- nek. Gruczoły wargowe (glandulae labiales) są to drobne, surowiczo-śluzowe gruczoły ślinowe, które umiejscowione są pod błoną śluzową, często wpuklone w obręb mięśni. Są one wyczuwalne palpacyjnie jako małe grudki, a czasem widoczne po naciągnięciu wargi. Klinicznie w tej części jamy ustnej często mamy do czynienia z torbielami zastoinowymi (mucocelami). W złożonych jednostkach chorobowych dochodzi do upośledzenia funkcjonowania tych gruczołów, a w gruczołowym zapaleniu warg może również wystąpić rozrost i nadczynność. Charakterystyczne dla tej patologii jest poszerzenie przewodów wyprowadzających drobnych gruczołów ślinowych rozmieszczonych w okolicy strefy Kleina wraz z nadmiernym ślinieniem. 
Liszaj twardzinowy charakteryzuje się przewlekłym procesem zapalnym, któremu towarzyszą remisje i zaostrzenia [8]. Jednostka chorobowa częściej spotykana jest u kobiet, szczególnie w okresie pomenopauzalnym [8-11]. Najczęściej zmiany umiejscawiają się w okolicy narządów płciowych oraz okołoodbytniczej, ale mogą pojawiać się w każdym regionie skóry, w szczególności klatki piersiowej, pleców, piersi, szyi, nadgarstków [9, 11, 12]. Liszaj twardzinowy w jamie ustnej występuje bardzo rzadko [12-14], dlatego w anglojęzycznej literaturze medycznej opisano tylko 41 histologicznie potwierdzone przypadki [15]. Zmiany mogą obejmować policzki, podniebienie, język i dziąsła [15], natomiast te występujące na wargach są często pomijane z powodu niewielkich rozmiarów [16]. Zmiany na dziąsłach mogą prowadzić do powstawania recesji dziąsłowych, utraty przyczepu łącznotkankowego, a nawet wywołać ruchomość zębów [17-19]. Liszaj twardzinowy obejmujący jamę ustną, w przeciwieństwie do pozostałych lokalizacji, rzadko daje objawy, ale może powodować ból, świąd, pieczenie gardła oraz sprawiać trudności podczas otwierania ust [14, 17-23]. W obrazie klinicznym charakteryzuje się występowaniem białawych plam lub płytek z dobrze zaznaczoną granicą zmiany $[24,25]$. Przyczyna powstawania tej jednostki chorobowej nie jest do końca poznana. Podejrzewa się reakcje autoimmunologiczne, dla których charakterystyczne jest występowanie autoprzeciwciał, takich jak białko macierzy zewnątrzkomórkowej 1 [26], membrany antyseptycznej (BP180 i BP230) [27, 28] i przeciwciał przeciwtarczycowych [29]. Interleukina-1 oraz receptor antagonisty (IL-1ra) również mogą być odpowiedzialne za wystąpienie objawów liszaja twardzinowego [30]. Poziom hormonów odgrywa istotną rolę, ponieważ jednostka chorobowa częściej występuję w okresie przed i pomenopauzalnym, spotykana u kobiet z zespołem Turnera [31], a znaczna poprawa następuje w okresie ciąży. Liszaj twardzinowy w 17\% przypadków występował rodzinnie [32], obserwowano również korelację pomiędzy antygenami leukocytów HLA a ryzykiem pojawienia się choroby [33-36]. Innymi czynnikami mogącymi mieć wpływ na zainicjowanie schorzenia są współtowarzyszące infekcje wirusowe: Epsteina-Barr [8, 37], brodawczaka ludzkiego (HPV) [38], zapalenia wątroby typu C [39] oraz bakteryjne Borreliq burgdorferi [40]. Znaczenie ma również podrażnianie czynnikami chemicznymi i mechanicznymi, takimi jak urazy, otarcia, blizny [11] czy miejsca po radioterapii.

W niniejszej pracy przedstawiono opis przypadku rzadko występującego obrazu zapalenia gruczołów ślinowych warg oraz dna przedsionka w żuchwie u pacjentki z długoletnim wywiadem leczenia liszaja twardzinowego.

\section{Opis przypadku}

64-letnia kobieta (K.B.) została skierowana do Zakładu Chorób Błony Śluzowej Jamy Ustnej i Przyzębia Uniwersytetu Medycznego w Łodzi w maju 2016 roku z powodu pojawienia się zmian na błonie śluzowej jamy ustnej utrzymujących się od 6 miesięcy. Badaniem wewnątrzustnym wstępnie stwierdzono zmiany o charakterze pęcherzyków i grudek wraz z nadżerkami rozsianymi na wardze dolnej oraz w dnie przedsionka żuchwy po stronie lewej (Ryciny 1 i 2). Na policzkach zauważalne

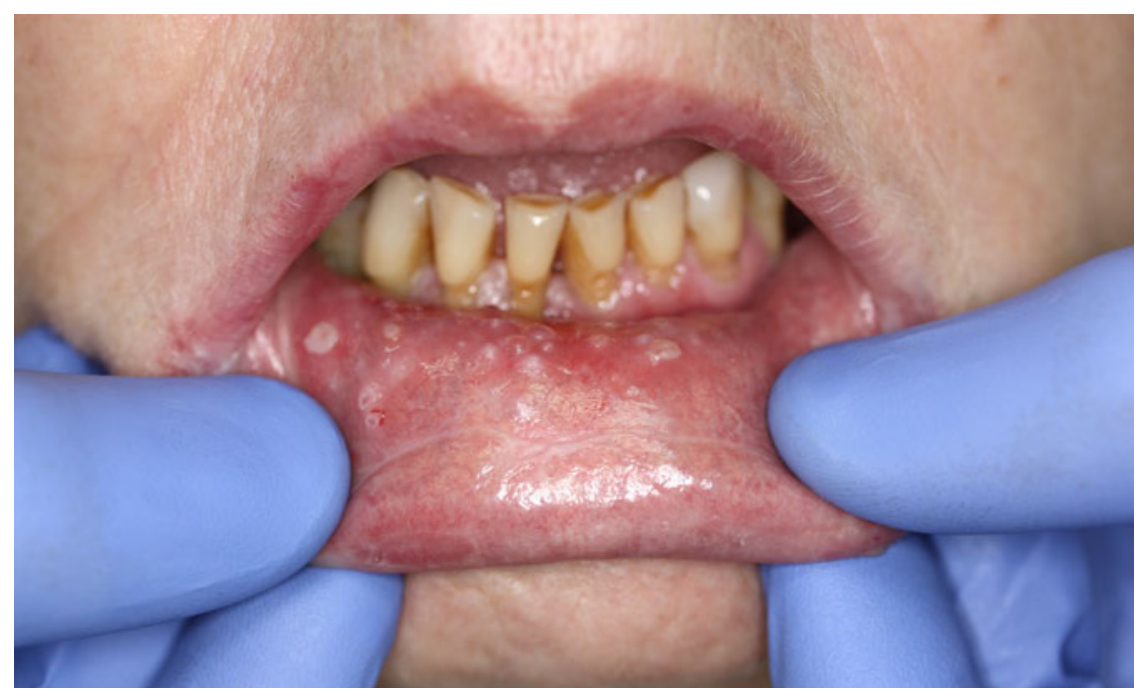

Rycina 1. Stan błony śluzowej wargi dolnej przed rozpoczęciem leczenia

Figure 1. Mucosa of the lower lip before treatment 


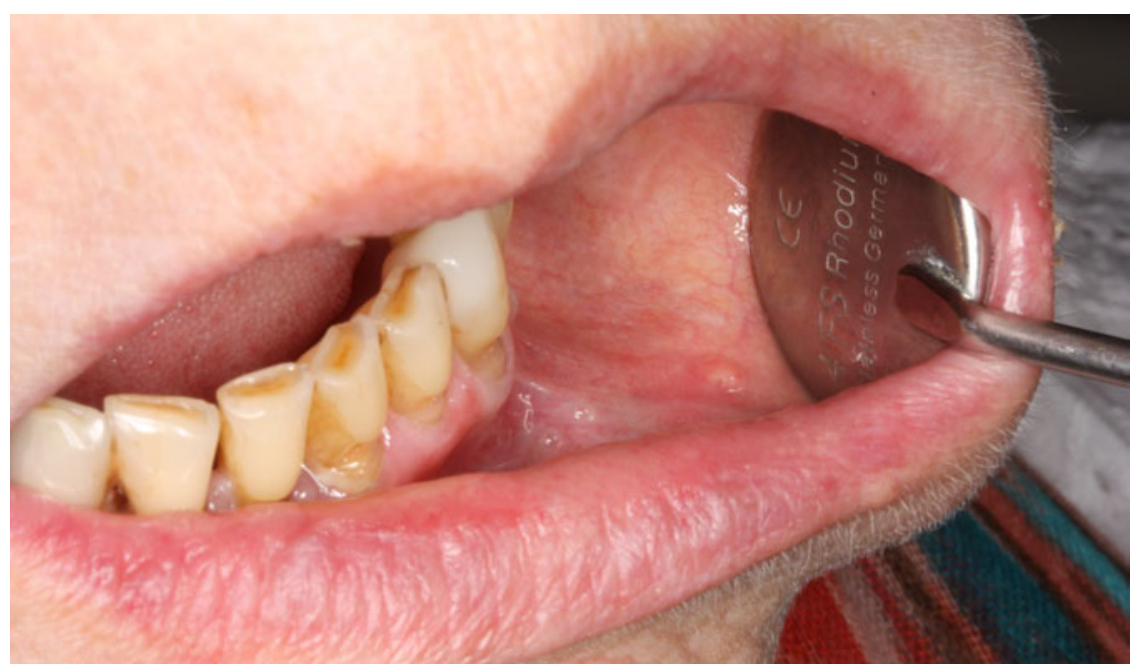

Rycina 2. Stan błony śluzowej w dnie przedsionka żuchwy po stronie lewej

Figure 2. Mucosa of the mandible vestibule left side before treatment

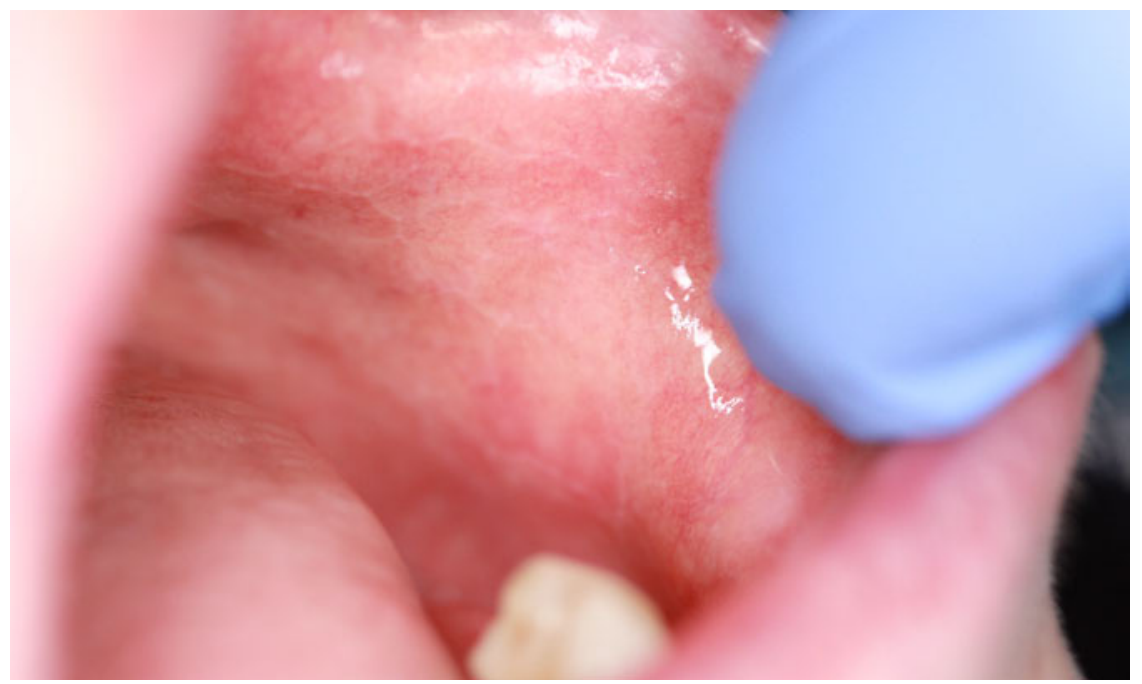

Rycina 3. Zmiany o typie liszaja płaskiego na błonie śluzowej policzka

Figure 3. Lichen planus-like lesions on buccal mucosa

zmiany o charakterze liszaja płaskiego (Rycina 3) oraz w okolicy lewego kąta ust zmiana zakwalifikowana jako leukokeratoza (Rycina 4).

Na podstawie badania podmiotowego ustalono, że w 2002 roku pacjentka została przyjęta do Kliniki Dermatologii z rozsianymi zmianami o typie liszaja twardzinowego zanikowego w obrębie tułowia oraz błony śluzowej narządów płciowych. W leczeniu zastosowano ogólnie sterydy, witaminę $\mathrm{E}$, iniekcje domięśniowe z Penicyliny prokainowej oraz leczenie miejscowe maścią parafinową, polcortolonową, Diprolene, tormentiol z lekobazą i Heparinum krem. Uzyskano zahamowanie poszerzania się ognisk, wygładzenie ich powierzchni oraz częściowe ustępowanie z powstawaniem przebarwień. Pacjentka została wypisana ze szpitala po siedemnastodniowej hospitalizacji.
W 2009 roku chora trafiła na Oddział Ginekologii z wstępnym rozpoznaniem liszaja twardzinowego sromu. Po pobraniu wycinka na własną prośbę została wypisana do domu. W badaniu histopatologicznym zobrazowano nabłonek wielowarstwowy płaski ze zmianami przerostowo-rozrostowymi (rozrost akantotyczny), z pogrubieniem warstwy ziarnistej i umiarkowanym, przewlekłym, nieswoistym procesem zapalnym.

W chwili badania pacjentka nie przyjmowała żadnych leków. W wywiadzie brak uczuleń oraz nałogów. Podała, że jest pod wpływem silnego i przewlekłego stresu. Pacjentka narzekała na odczuwanie słonego posmaku w ustach oraz pojawianie się dolegliwości bólowych w sytuacjach, kiedy dochodzi do drobnych urazów mechanicznych w obrębie wargi dolnej. Odczuwała również nadwrażliwość 


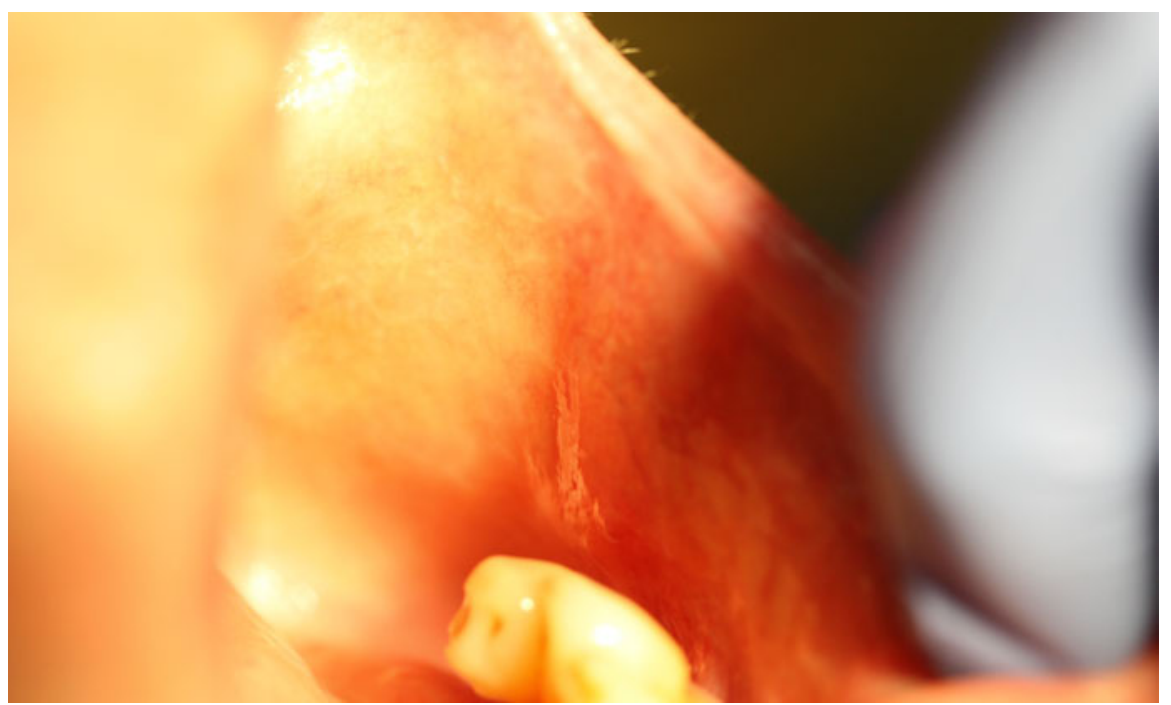

Rycina 4. Zmiana w okolicy lewego kąta ust

Figure 4. White lesion in the left commissure area

na bodźce termiczne oraz ostre i kwaśne składniki diety na całej błonie śluzowej jamy ustnej.

$\mathrm{Na}$ wardze dolnej zaobserwowano kilkanaście okrągłych zmian o średnicy ok. $2 \mathrm{~mm}$, w dnie przedsionka żuchwy po stronie lewej klika zmian o tym samym wyglądzie. Klinicznie niektóre zmiany przypominały drobne torbiele zastoinowe (mucocele), część z pokrywą martwiczą. Na obu policzkach zdiagnozowano zmiany o charakterze liszaja płaskiego z charakterystyczną siateczką Wickhama, zauważalną również na wardze dolnej. W okolicy lewego kąta ust na błonie śluzowej zmiana przypominająca leukokeratozę, która ze względu na wywiad mogła być zmianą o typie liszaja twardzinowego.
Zalecono miejscowe stosowanie 0,05\% klobetazolu na policzki, a wargę poddano dalszej obserwacji bez wprowadzania leczenia. Poinformowano pacjentkę o konieczności zastosowania łagodnej diety. Jednocześnie pacjentka została poproszona o wykonanie badań morfologii krwi, prób wątrobowych oraz diagnostyki w kierunku WZW typu B i C. Po 2 tygodniach zmiany o charakterze liszaja płaskiego oraz zmiana w okolicy lewego kąta ust uległy prawie całkowitemu wygojeniu, natomiast zmiany na wardze dolnej nie uległy poprawie. Badania laboratoryjne nie wykazały znaczących odstępstw od normy. Podjęto decyzję o pobraniu wycinka z wargi dolnej do badania histopatologicznego, a pacjentce zalecono stosowanie 0,05\%

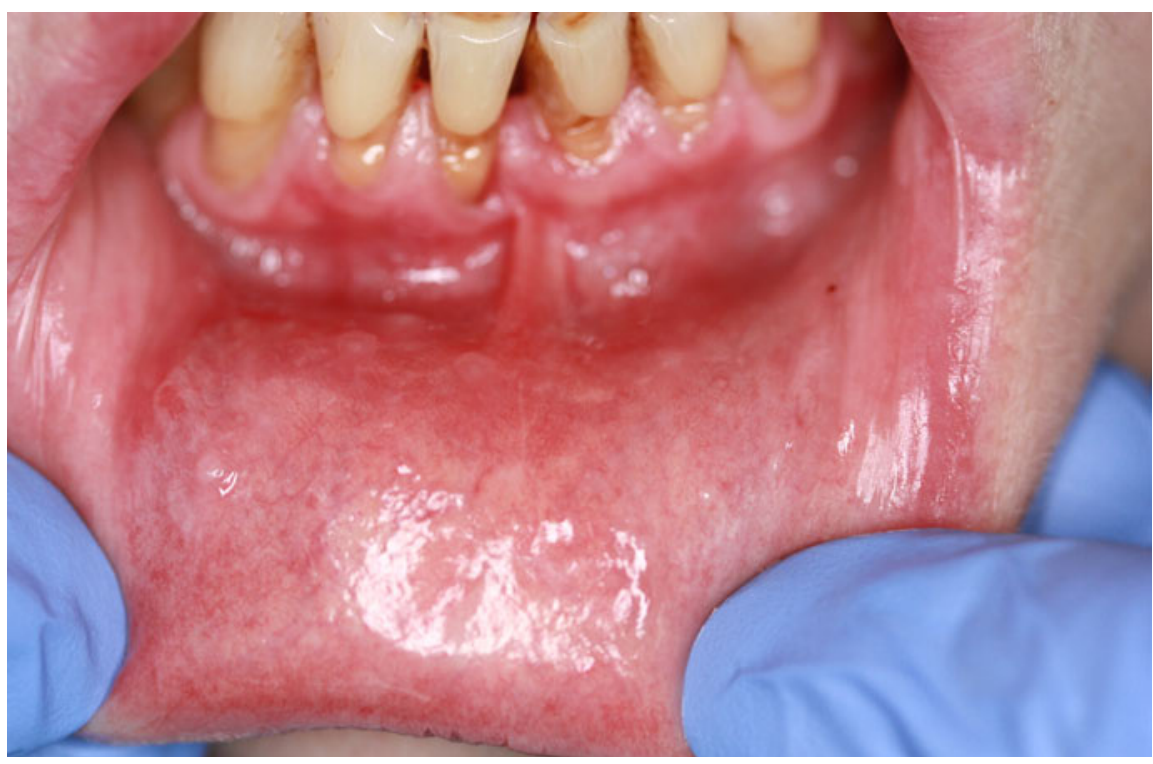

Rycina 5. Stan błony śluzowej wargi dolnej po leczeniu

Figure 5. Mucosa of the lower lip after treatment 
klobetazolu na wargę dolną w osłonie przeciwgrzybiczej. Na wizycie kontrolnej po 2 tygodniach zaobserwowano wycofywanie się zmian na wardze dolnej. Otrzymano wynik badania histopatologicznego o następującym rozpoznaniu: sialadenitis chronica exacerbata. Po miesiącu od zakończenia terapii zaobserwowano znaczną poprawę: brak wznowy liszaja płaskiego oraz pojedyncze wynicowane drobne gruczoły ślinowe na wardze dolnej. Zastosowano dodatkowo lek o działaniu przeciwalergicznym zawierający feksofenadynę. Na kolejnych wizytach kontrolnych po 1, 3 i 6 miesiącach stan nie uległ pogorszeniu, jednak wciąż zauważalne były gruczoły ślinowe (Rycina 5).

\section{Podsumowanie}

Liszaj twardzinowy przez niektórych autorów jest uznawany za przewlekłą jednostkę chorobową, którą należy leczyć przez całe życie [41, 42]. Początkowe zmiany mogą nakładać się $\mathrm{w}$ badaniu histologicznym na obraz liszaja płaskiego [8]. U pacjentki zmiany na policzkach były bardzo charakterystyczne dla siateczkowej postaci liszaja płaskiego, natomiast na wardze po naciągnięciu błony śluzowej delikatna biała siateczka była również zauważalna pomiędzy widocznymi gruczołami. Zmiana w okolicy lewego kąta ust wskazywała na leukokeratozę na tle urazowym, ale nie można było wykluczyć początkowej zmiany o typie liszaja twardzinowego. Pochodzenie obu jednostek chorobowych jest złożone i najczęściej wyróżnia się czynniki genetyczne i autoimmunologiczne w jednej i drugiej postaci liszaja $[8,43]$. Pacjentka nie paliła, ale wskazała na stałe narażenie silnym stresem. Nie zauważyła obecności białych zmian na błonach śluzowych, bardziej zaniepokoiła ją obecność zaznaczonych gruczołów ślinowych na wardze dolnej, które po badaniu zostały również zlokalizowane w mniejszej liczbie w dnie przedsionka żuchwy po stronie lewej. Nie zdiagnozowano zmian ocznych ani stawowych w chwili badania, a pacjentka zgłaszała jedynie wrażliwość na ciepłe i ostre pokarmy, słony posmak w ustach, ale bez subiektywnej i klinicznie widocznej suchości błon śluzowych. Podczas jedzenia i wykonywania czynności higienizacyjnych jamy ustnej dochodziło do urazów zewnętrznej powierzchni gruczołów ślinowych, co wzmagało dolegliwości bólowe oraz powodowało miejscową martwicę. Pacjentka z własnych obserwacji podała, że obrzęk gruczołów ślinowych po urazie wycofywał się samoistnie i po pewnym czasie pojawiał się $w$ innych miejscach. W zapaleniu gruczołowym warg zmiany mają skłonność do występowania na wardze dolnej, ze wskazaniem na częstsze pojawianie się u mężczyzn w wieku 40-70 lat [44]. Zaniedbania higienizacyjne i palenie papierosów sprzyjają pojawieniu się objawów. Drugorzędowa postać tego schorzenia może uaktywnić się na skutek stałego drażnienia w tej okolicy $n p$. w liszaju płaskim [45]. Ze względu na złożony problem i nałożenie się kilku jednostek chorobowych rozpoczęto leczenie miejscowe klobetazolem, który jest jednym z zalecanych leków pierwszego rzutu w leczeniu tych postaci liszaja $[8,46,47]$. Na pierwszej wizycie kontrolnej uzyskano bardzo dobrą odpowiedź na podjęte leczenie $w$ obrębie zmian na policzkach. Ze względu na to, że zmiany na wardze nie uległy samoistnej poprawie, pobrano wycinek do badania histopatologicznego. Następnie pacjentka kontynuowała leczenie miejscowym sterydem w osłonie przeciwgrzybiczej również $w$ tym obszarze jamy ustnej, ponieważ zmiany o typie liszaja płaskiego były zauważalne przy uwypuklonych gruczołach ślinowych. Zastosowano dodatkowo Nystatynę w zawiesinie, aby uniknąć powikłań grzybicą rzekomobłoniastą, czyli nadmiernego rozrostu Candida spp. na skutek długoczasowego miejscowego stosowania kortykosteroidu [48-53]. Kolejne wizyty potwierdziły, że efekt terapeutyczny był zadowalający, pacjentka również zgłaszała ustępowanie dolegliwości. Jednak nie uzyskano całkowitego wyleczenia zapalenia drobnych gruczołów ślinowych, pacjentka również przyznawała, że nie utrzymuje stale diety i dochodzi do zaostrzeń objawów po spożyciu ostrych, kwaśnych czy gorących pokarmów. Złożoność problemu, podejrzenie czynnika autoimmunologicznego, niecałkowite przestrzeganie zaleceń mogły sprawiać, że zmiany nie ulegały całkowitemu wyleczeniu. Rozpatrywano u pacjentki podjęcie leczenia chirurgicznego, ponieważ w miejscu pobranego wycinka zmiany nie nawracały, jednak pacjentka nie wyraziła zgody na to leczenie.

Liszaj twardzinowy oraz zapalenie gruczołów ślinowych mogą mieć podłoże autoimmunologiczne oraz wystąpić przy infekcjach wirusowych i bakteryjnych, co mogłoby wskazywać na częściowo wspólną etiologię. $W$ piśmiennictwie nie ma jednak potwierdzenia powiązania tych chorób, co na tym etapie wiedzy zmusza do traktowania schorzeń jako dwóch niezależnych od siebie jednostek.

\section{Oświadczenia \\ Oświadczenie dotyczące konfliktu interesów Autorzy deklarują brak konfliktu interesów w autorstwie oraz publikacji pracy.}

Źródła finansowania

Autorzy deklarują brak źródeł finansowania. 


\section{Piśmiennictwo}

[1] Razek A, Mukherji S. Imaging of sialadenitis. The Neuroradiology Journal. 2017;0(00):1-11.

[2] Carlson ER. Diagnosis and management of salivary gland infections. Oral Maxillofac Surg Clin North Am. 2009;21:293-312.

[3] Zenk J, Iro H, Klintworth N, et al. Diagnostic imaging in sialadenitis. Oral Maxillofacial Surg Clin North Am. 2009;21:275-292.

[4] Mandel L. Salivary gland disorders. Med Clin North Am. 2014;98:1407-1449.

[5] Madani $G$ and Beale T. Inflammatory conditions of the salivary glands. Semin Ultrasound CT MRI. 2006;27:440-451.

[6] Francis CL and Larsen C. Pediatric sialadenitis. Otolaryngol Clin North Am. 2014;47:763-778.

[7] Thomas BL, Brown JE and McGurk M. Salivary gland disease. Front Oral Bio. 2010;14:129-146.

[8] Fistarol SK, Itin PH. Diagnosis and treatment of lichen sclerosus: an update. Am J Clin Dermatol. 2013;14:27-47.

[9] Kirtschig G. Lichen sclerosus - presentation, diagnosis and management. Dtsch Arztebl Int. 2016;113:337-43.

[10] Meffert JJ, Davis BM, Grimwood RE. Lichen sclerosus. J Am Acad Dermatol. 1995;32:393-416.

[11] Powell JJ, Wojnarowska F. Lichen sclerosus. Lancet. 1999;353:1777-1783.

[12] Neill SM, Tatnall FM, Cox NH, British Association of Dermatologists. Guidelines for the management of lichen sclerosus. Br J Dermatol. 2002;147:640-649.

[13] James W, Berger T, Elston D. Andrews' Diseases of the Skin, 11th edn. US: Saunders, 2011.

[14] Azevedo RS, Romañach MJ, de Almeida OP, et al. Lichen sclerosus of the oral mucosa: clinicopathological features of six cases. Int J Oral Maxillofac Surg. 2009;38:855-860.

[15] Tuomas Kakko1, Tuula Salo, DDS, Maria K. Siponen. Oral lichen sclerosus: a systematic review of reported cases and two new cases. Review. International Journal Of Dermatology. 2017:1-8.

[16] AttiliVR, AttiliSK. Lichen sclerosus of lips: aclinicaland histopathologicstudy of 27cases. IntJDermatol. 2010;49:520-525.

[17] Jimenez Y, Bagan JV, Milian MA, et al. Lichen sclerosus et atrophicus manifesting with localized loss of periodontal attachment. Oral Dis. 2002;8:310-313.

[18] Kaur S, Thami GP, Kanwar AJ, et al. Linear oro-facial lichen sclerosus. Clin Exp Dermatol. 2002;27:467-470.

[19] Jimenez Y, Gavalda C, Carbonell E, et al. Lichen sclerosus of the oral mucosa: a case report. Med Oral Patol Oral Cir Bucal. 2008;13:403-406.

[20] Siar $\mathrm{CH}, \mathrm{Ng} \mathrm{KH}$. Oral lichen sclerosus et atrophicus: report of a case. J Oral Med. 1985;40:148-150.

[21] Macleod RI, Soames JV. Lichen scleroses et atrophicus of the oral mucosa. Br J Oral Maxillofac Surg. 1991;29:64-65.

[22] Buajeeb W, Kraivaphan P, Punyasingh J, et al. Oral lichen sclerosus et atrophicus. A case report. Oral Surg Oral Med Oral Pathol Oral Radiol Endod. 1999;88:702-706.
[23] Chaudhry SI, Morgan PR, Neill SM. An unusual tongue. Clin Exp Dermatol. 2006;31:831-832.

[24] Liu Y, Hua H, Gao Y. Oral lichen sclerosus et atrophicus - literature review and two clinical cases. Chin J Dent Res. 2013;16:157-160.

[25] Marangon Junior H, Souza PEA, Soares RV, et al. Oral lichen sclerosus: a rare case report and review of the literature. Head Neck Pathol. 2017;11:212-218.

[26] Oyama N, Chan I, Neill SM, et al. Development of antigen-specific ELISA for circulating autoantibodies to extracellular matrix protein 1 in lichen sclerosus. J Clin Invest. 2004;113:1550-9.

[27] Howard A, Dean D, Cooper S, Kirtshig G, Wojnarowska F. Circulating basement membrane zone antibodies are found in lichen sclerosus of the vulva. Australas J Dermatol. 2004;45:12-15.

[28] Strittmatter HJ, Hengge UR, Blecken SR. Calcineurin antagonists in vulvar lichen sclerosus. Arch Gynecol Obstet. 2006;274:266-70.

[29] Kreuter A, Kryvosheyeva Y, Terras S, et al. Association of autoimmune diseases with lichen sclerosus in 532 male and female patients. Acta Derm Venereol. 2013;93:238-41.

[30] Clay FE, Cork MJ, Tarlow JK, et al. Interleukin 1 receptor antagonist gene polymorphism association with lichen sclerosus. Hum Genet. 1994;94:407-10.

[31] Haidopoulos D, Bakolas G, Michala L. Turner syndrome: don't forget the vulva. Endocrinol Diabetes Metab Case Reports. 2016;2016:160016.

[32] Powell J, Wojnarowska F. Childhood vulvar lichen sclerosus: an increasingly common problem. J Am Acad Dermatol. 2001;44:803-6.

[33] Powell J, Wojnarowska F, Winsey S, Marren P, Welsh K. Lichen sclerosus premenarche: autoimmunity and immunogenetics. Br J Dermatol. 2000;142:481-4.

[34] Purcell KG, Spencer LV, Simpson PM, Helman SW, Oldfather JW, Fowler JF. HLA antigens in lichen sclerosus et atrophicus. Arch Dermatol. 1990;126:1043-5.

[35] Sentürk N, Aydin F, Birinci A, et al. Coexistence of $H L A-B^{*} 08$ and $H L A-B^{*} 18$ in four siblings with Lichen sclerosus. Dermatology. 2004;208:64-6.

[36] Gao X-H, Barnardo MC, Winsey S, et al. The association between HLA DR, DQ antigens, and vulval lichen sclerosus in the UK: HLA DRB112 and its associated DRB112/DQB10301/04/09/010 haplotype confers susceptibility to vulval lichen sclerosus, and HLA DRB10301/04 and its associated DRB10301/04/ DQB10201/02/03 haplotype protects from vulval lichen sclerosus. J Invest Dermatol. 2005;125:895-9.

[37] Aidé S, Lattario FR, Almeida G, do Val IC, da Costa Carvalho M. Epstein-Barr virus and human papillomavirus infection in vulvar lichen sclerosus. J Low Genit Tract Dis. 2010;14:319-22.

[38] Powell J, Strauss S, Gray J, Wojnarowska F. Genital carriage of human papilloma virus (HPV) DNA in prepubertal girls with and without vulval disease. Pediatr Dermatol. 2003;20:191-4.

[39] Bunker C, Shim T. Male genital lichen sclerosus. Indian J Dermatol. 2015;60:111-17.

[40] Eisendle K. Possible role of Borrelia burgdorferi sensu lato infection in lichen sclerosus. Arch Dermatol. 2008;144:591-8. 
[41] Lee A, Bradford J, Fischer G. Long-term Management of adult vulvar lichen sclerosus: a prospective cohort study of 507 women. JAMA Dermatol. 2015;151:1061-7.

[42] Perez-Lopez FR, Ceausu I, Depypere H, et al. EMAS clinical guide: vulvar lichen sclerosus in peri and postmenopausal women. Maturitas. 2013;74:279-82.

[43] Scully C, Beyli M, Ferreiro MC et al. Update on oral lichen planus: etiopathogenesis and management. Crit Rev Oral Biol Med. 1998;9:86-122.

[44] Górska R. Diagnostyka i leczenie chorób błony śluzowej jamy ustnej. Med. Tour Press International. Otwock. 2011;3:68-69.

[45] Bermejo A1, Aguirre JM, López P, Saez MR. Superficial mucocele: report of 4 cases. Oral Surg Oral Med Oral Pathol Oral Radiol Endod. 1999 Oct;88(4):469-72.

[46] Carbone M, Conrotto D, Carrozzo M et al. Topical corticosteroids in association with miconazole and chlorhexidine in the long-term management of atrophic-erosive oral lichen planus: a placebo controlled and comparative study between clobetasol and fluocinonide. Oral Dis. 1999;5:44-9.

[47] Campisi G, Giandalia G, De Caro V et al. A new delivery system of clobetasol-17 propionate (lipid-loaded microspheres $0.025 \%$ ) compared with a conventional formulation (lipophilic ointment in a hydrophilic phase $0.025 \%$ ) in topical treatment of atrophic/erosive oral lichen planus. A phase IV, randomized, observer-blinded, parallel group clinical trial. Br J Dermatol. 2004;150:984-90.

[48] Vincent SD, Fotos PG, Baker KA, et al. Oral lichen planus: the clinical, historical, and therapeutic features of 100 cases. Oral Surg Oral Med Oral Pathol. 1990;70:165-71.

[49] Vincent SD, Lilly GE, Baker KA. Clinical, historic, and therapeutic features of iatrical pemphigoid: a li- terature review and open therapeutic trial with corticosteroids. Oral Surg Oral Med Oral Pathol. 1993;76:453-9.

[50] Carbone M, Carrozzo M, Broccoletti R, et al. A topical treatment of atrophic-erosive oral lichen planus with flucinonide in a bio adhesive gel, chlorhexidine and miconazole gel: a totally open trial. Minerva Stomatol. 1996;45:61-8.

[51] Epstein JB, Komiyama K, Duncan D. Oral topical steroids and secondary oral candidiasis. J Oral Med. 1986;41:223-7.

[52] Thongprasom K, Luengvisut $P$, Wongwatanakij A, Boonjattutus $C$. Clinical evaluation in treatment of oral lichen planus with topical fluocinolone acetonide: a 2-year follow-up. J Oral Pathol Med. 2003;32:315-22.

[53] Thongprasom K, Luangjarmekorn L, Sererat T, Taweesap W. Relative efficacy of flucinolone acetonide compared with triamcinolone acetonide in treatment of oral lichen planus. J Oral Pathol Med. 1992;21:456-8.

Zaakceptowano do edycji: 2018-10-16 Zaakceptowano do publikacji: 2018-12-05

Adres do korespondencji:

Adrian Królak

ul. Kochanowskiego 39, 95-200 Pabianice

tel.: 695504199

e-mail: adrian.krolak@wp.pl 